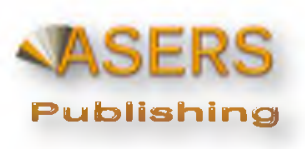

DOI: https://doi.org/10.14505/jarle.v8.8(30).32

\title{
Import Substitution in the Belgorod Region in the Context of Economic Security
}

\author{
Elena Anatolyevna STRYABKOVA \\ The National Research University 'Belgorod State University', Belgorod, Russian Federation \\ stryabkova@bsu.edu.ru \\ Anna Mikhailovna KULIK \\ The National Research University 'Belgorod State University', Belgorod, Russian Federation \\ kulik@bsu.edu.ru \\ Natalya Anatolyevna GERASIMOVA \\ The National Research University 'Belgorod State University', Belgorod, Russian Federation \\ ngerasimova@bsu.edu.ru \\ Elena Petrovna DRUZHNIKOVA \\ The National Research University 'Belgorod State University', Belgorod, Russian Federation \\ druzhnikova@bsu.edu.ru \\ Anna Nikolaevna KOGTEVA \\ The National Research University 'Belgorod State University', Belgorod, Russian Federation \\ kogteva@bsu.edu.ru
}

\section{Suggested Citation:}

Stryabkova, Elena Anatolyevna et al. 2017. Import Substitution in the Belgorod Region in the Context of Economic Security, Journal of Advanced Research in Law and Economics, Volume VIII, Winter, 8(30): $2605-2617$. DOI: 10.14505/jarle.v8.8(30).32. Available from: http://journals.aserspublishing.eufjarle/index

\section{Article's History:}

Received September, 2017; Revised October, 2017; Published December, 2017.

Copyright ${ }^{\circledR} 2017$, by ASERS ${ }^{\circledR}$ Publishing. All rights reserved.

\begin{abstract}
:
Today the issue regarding the need for import substitution has become particularly relevant in consequence of the application of economic sanctions against Russia in 2014, as well as the subsequent decrease in prices of primary recourses, sharp depreciation of the Russian ruble against world currencies, the blocking of access to credits on international financial markets, and termination of technology transfer. This has led the Russian economy to such a situation, where the issue arose about the need of mobilizing internal resources to support the economy and prevent its collapse. The present article uses scientific methods and general scientific principles of dialectical development and systematic approach. The major results concern the estimation of the food basket in the Belgorod region, discussions on the current status of the regional import substitution system, an evaluation of the effectiveness of state regulation measures of the import substitution policy, the formation of priority guidelines of import substitution in the context of increasing economic security of the Belgorod region.
\end{abstract}

Keywords: import substitution; consumer basket; minimum cost of living; the level of self-sufficiency; economic security of the region.

JEL Classification: D40; D49.

\section{Introduction}

In contemporary economic conditions the issue of food security, as well as the issue of import substitution as a mechanism to ensure food security and increase competitiveness, plays an important role. The economic interpretation characterizes the import substitution in Russia as an active process aimed at replacement of imports by domestic goods or services. 
Note that to date there is extremely large number of strategies, concepts, regulations and government programs, which somehow use the term of 'import substitution'. This makes it difficult to formulate a goal, objectives, and projected outcomes of this economic policy direction in the country, leads to inefficient expenditure of budget funds, which are allocated for various measures to support domestic producers. As a result, the effectiveness of the implementation of decisions taken leaves much to be desired (Maslov 2014).

The relevance of the considered topic is due to the current situation in the import substitution, which requires carrying out more profound analysis of the current state of affairs and establishing compliance of the declared and actual results of import substitution in 2017 to achieve intended outcomes.

\section{Methods}

The presented article is written using modern scientific apparatus and tooling, various research methods and approaches such as historical, economic-statistical, systematic and analytical, expert assessment, analogies, etc.

\section{Results}

\subsection{Assessment of the Food Basket in the Belgorod Region}

While considering the data of the Federal Service for State Statistics, we can conclude that one of the cheapest consumer baskets falls to the Belgorod region. In January 2016 a food basket valued at 3022 rubles 30 kopecks. Note that the consumer basket is characterized by a certain set of goods and services, providing full life-sustaining for a person for a particular year that satisfies his minimal needs. A subsistence level depends on the consumer basket. At that, it should be noted that the subsistence level is reviewed each year and depends on the level of prices. While considering the main socio-demographic groups of the regional population, note that the composition of the consumer basket is set at least once within five years.

Table 1 below presents foods and their volumes for different socio-demographic groups of population in the Belgorod region taking into account their needs in food consumption.

Table 1. The assessment of the consumer basket in the Belgorod region for the period $2013-2018$

\begin{tabular}{|c|c|c|c|c|}
\hline Item & $\begin{array}{l}\text { Unit of } \\
\text { measurement }\end{array}$ & $\begin{array}{l}\text { The cons } \\
\text { (on average } \\
\text { Able-bodied } \\
\text { population }\end{array}$ & $\begin{array}{l}\text { umption volume } \\
\text { Hor person per } \\
\text { Hers of an } \\
\text { annuity }\end{array}$ & Children \\
\hline $\begin{array}{l}\text { Bread products (bread and pasta expressed in terms of } \\
\text { flour, cereals, and legumes) }\end{array}$ & gram & 128,400 & 98,700 & 78,300 \\
\hline Potatoes & gram & 100,500 & 80,000 & 88,400 \\
\hline Vegetables and melons & gram & 115,200 & 99,000 & 113,400 \\
\hline Fresh fruit & gram & 60,000 & 45,000 & 118,100 \\
\hline $\begin{array}{l}\text { Sugar and confectionery } \\
\text { expressed in terms of sugar }\end{array}$ & gram & 22,200 & 21,200 & 21,900 \\
\hline Meat products & gram & 58,700 & 54,000 & 44,400 \\
\hline Fish products & gram & 19,000 & 17,000 & 18,600 \\
\hline Dairy products in milk equivalent & gram & 290,800 & 267,800 & 359,500 \\
\hline Eggs & items & 210 & 200 & 201 \\
\hline Vegetable oil, margarine, and other fats & gram & 11,500 & 9,000 & 5,900 \\
\hline Other products (salt, tea, spices) & gram & 4,900 & 4,100 & 3,500 \\
\hline
\end{tabular}

It can be concluded that able-bodied population uses more food products comparing to what is expected and predicted. Also note that children need much more food products than people of retirement age. In order to compare, we present data on the composition of the food basket in the Russian Federation, presented in Table 2. 
Table 2. The assessment of the consumer basket in the Russian Federation for the period $2013-2018$

\begin{tabular}{|c|c|c|c|c|}
\hline \multirow[t]{2}{*}{ Item } & \multirow{2}{*}{$\begin{array}{l}\text { Unit of } \\
\text { measurement }\end{array}$} & \multicolumn{2}{|c|}{$\begin{array}{l}\text { The consumption volume } \\
\text { (on average per person per year) }\end{array}$} & \multirow[b]{2}{*}{ Children } \\
\hline & & $\begin{array}{l}\text { Able-bodied } \\
\text { population }\end{array}$ & $\begin{array}{r}\text { Holders of an } \\
\text { annuity }\end{array}$ & \\
\hline $\begin{array}{l}\text { Bread products (bread and pasta expressed } \\
\text { in terms of flour, cereals, and legumes) }\end{array}$ & gram & 126,500 & 98,200 & 76,600 \\
\hline Potatoes & gram & 100,400 & 80,000 & 88,100 \\
\hline Vegetables and melons & gram & 114,600 & 98,000 & 112,500 \\
\hline Fresh fruit & gram & 60,000 & 45,000 & 118,100 \\
\hline $\begin{array}{l}\text { Sugar and confectionery } \\
\text { expressed in terms of sugar }\end{array}$ & gram & 23,800 & 21,200 & 21,800 \\
\hline Meat products & gram & 58,600 & 54,000 & 44,000 \\
\hline Fish products & gram & 18,500 & 16,000 & 18,600 \\
\hline Dairy products in milk equivalent & gram & 290,000 & 257,800 & 360,700 \\
\hline Eggs & items & 210 & 200 & 201 \\
\hline Vegetable oil, margarine, and other fats & gram & 11,000 & 10,000 & 5,000 \\
\hline Other products (salt, tea, spices) & gram & 4,900 & 4,200 & 3,600 \\
\hline
\end{tabular}

Thus, based on the comparison of the food basket in the Russian Federation and in the Belgorod region, we can conclude that the consumption of food in the Belgorod region per person per year is at the average greater than that in Russia. These high indicators are explained by the fact that the Belgorod region is actively involved in the construction of new meat factories and greenhouses for growing vegetables and berries that have been implemented in the region at a high enough level. Besides, the Belgorod region is characterized by a high level of poultry farming, that is, we can say that the Belgorod region is provided with goods produced in amounts larger than are defined by the food basket (Central statistical database, n.d.).

Next, we consider the consumer baskets in different regions of the Russian Federation. The relevant information is presented in Table 3.

Table 3. The composition of the consumer basket for the able-bodied population in different regions, 2016

\begin{tabular}{|c|c|c|c|c|c|c|c|c|c|c|c|}
\hline$\frac{\text { 흥 }}{\mathbb{d}}$ & $\begin{array}{l}\text { 을 } \\
\text { 흠 } \\
\text { 흠 } \\
\text { 흉 }\end{array}$ & 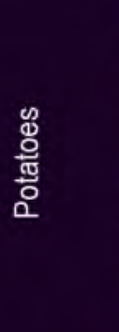 & 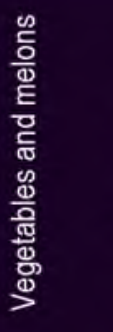 & 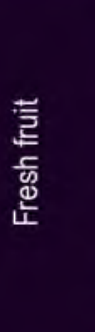 & 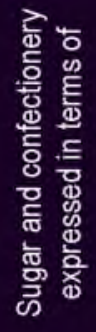 & 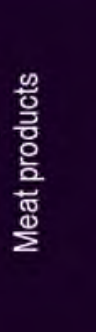 & $\begin{array}{l}\frac{\omega}{0} \\
\frac{0}{0} \\
\frac{0}{2} \\
\frac{5}{0} \\
\frac{0}{4}\end{array}$ & 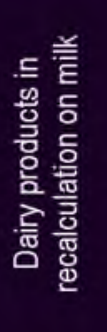 & $\begin{array}{l}\text { : } \\
\text { 兽 }\end{array}$ & 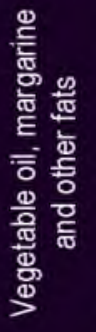 & 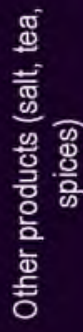 \\
\hline & $g$ & $g$ & $g$ & $g$ & $g$ & $g$ & $g$ & $\mathrm{~g}$ & item & g & g \\
\hline Kostroma region & 128400 & 100500 & 115200 & 60000 & 22200 & 58700 & 19000 & 290.80 & 210.0 & 11500 & 4.900 \\
\hline Moscow & 130860 & 108500 & 115200 & 60000 & 22260 & 58700 & 19000 & 290.80 & 210.0 & 13320 & 4.900 \\
\hline Moscow region & 128400 & 100500 & 115200 & 60000 & 22200 & 58700 & 19000 & 290.80 & 210.0 & 11500 & 4.900 \\
\hline Murmansk region & 156800 & 82900 & 112600 & 65000 & 26300 & 70400 & 32600 & 260.80 & 261.0 & 15900 & 4.900 \\
\hline Tyumen region & 131400 & 93000 & 115200 & 60000 & 23800 & 58500 & 20000 & 240.80 & 210.0 & 12800 & 4.900 \\
\hline Nizhny Novgorod region & 131000 & 87800 & 121100 & 60000 & 23800 & 58500 & 20000 & 254.80 & 210.0 & 13000 & 4.900 \\
\hline
\end{tabular}




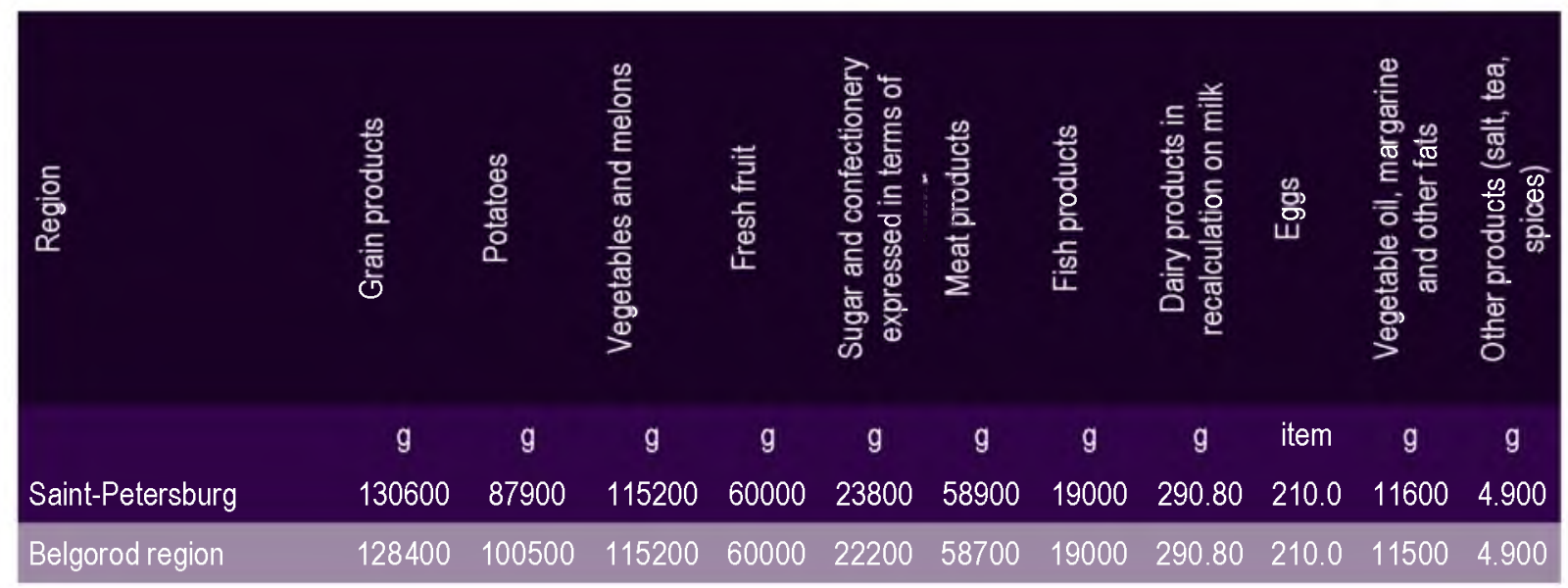

Analyzing the consumer basket of the able-bodied population in various regions of the Russian Federation, considering the consumer basket in the Belgorod region and that in, for example, Murmansk region, we came to the conclusion that the basket in the second case is filled with greater volume of essential products despite the fact that in contrast to the Murmansk region, the Belgorod region has sufficient domestic production of these goods. We also revealed that the indicators of the consumer basket are maximal in the Murmansk region, while minimal- in the Kostroma region.

The subsistence level is characterized by a minimum level of income at which certain groups of the population are able to maintain their livelihoods and pay for the essentials, such as food, accommodation, medical care, and a range of additional services. All of these products and services, which are included in the consumer basket, as well as the subsistence level, are determined based on food basket composition and the level of consumer prices (Vlasova 2012).

While considering the subsistence level calculation mechanism in terms of legislation, it should be noted that in the Russian Federation the level of the subsistence minimum is calculated in accordance with the Federal Law No. 134-FZ dated 24.10.1997 ('On subsistence minimum in the Russian Federation'). According to this document, the value of subsistence minimum must be reviewed each quarter in each subject of the Russian Federation

The subsistence minimum calculated for the Russian Federation in general at the federal level is needed to:

- define the living standards of the population in the Russian Federation;

- develop the main provisions of social policy based on determined subsistence minimum;

- develop and implement federal social programs based on determined subsistence minimum;

- adjust minimum living wage established at the federal level;

- determine stipends, allowances, and other social payments established at the federal level;

- draw up a budget at the federal level.

While considering the same issue at the regional level, the subsistence minimum is designed to:

- define the living standards of the population of the relevant entity of the Russian Federation at the development and implementation of regional social programs;

- provide the necessary government social assistance to needy citizens;

- draw up budgets of the Russian Federation entities (Federal Law No. 134-FZ, 1997).

Consider the level of subsistence minimum in the Belgorod region in 2015-2016, presented in Table 4.

Table 4. The definition of the average per capita subsistence minimum in the Belgorod region during 2015-2016 (rubles per month)

\begin{tabular}{lrrrrrrrrr}
\hline \multirow{2}{*}{ Indicator } & \multirow{2}{*}{ Percapita } & & \multicolumn{3}{c}{ Socio-demographic groups of the population } \\
& & & Able-bodied population & Holders of an annuity & \multicolumn{2}{c|}{ Children } \\
& 2015 & 2016 & 2015 & 2016 & 2015 & 2016 & 2015 & 2016 \\
\hline IQuarter & 8217.0 & 8105.0 & 8843.0 & 8703.0 & 6839.0 & 6744.0 & 8032.0 & 7999.0 \\
\hline IIQuarter & 8329.0 & 8221.0 & 8955.0 & 8826.0 & 6897.0 & 6822.0 & 8229.0 & 8150.0 \\
\hline
\end{tabular}




\begin{tabular}{|lllllllll|}
\hline \multirow{2}{*}{ Indicator } & \multirow{2}{*}{ Percapita } & \multicolumn{5}{c}{ Socio-demographic groups of the population } \\
& & & Able-bodied population & Holders of an annuity & Children \\
\hline IIIQuarter & 8073.0 & 8187.0 & 8694.0 & 8809.0 & 6727.0 & 6809.0 & 7854.0 & 8012.0 \\
\hline IVQuarter & 7918.0 & 8099.0 & 8526.0 & 8722.0 & 6621.0 & 6766.0 & 7668.0 & 7851.0 \\
\hline
\end{tabular}

We can conclude that by the $4^{\text {th }}$ quarter of 2015 per capita subsistence minimum was minimal. This decline is characterized by the fact that the cost of the consumer basket decreased. By the end of 2016,there was an increase in the subsistence minimum as compared to the $2^{\text {nd }}$ quarter of 2015, while in the $3^{\text {rd }}$ quarter of 2015 there was a slight decrease by 34.0 ruble that was primarily due to falling food commodity prices (Central statistical database, n.d.).

In order to make a comparison, we present data on the subsistence minimum in Russian Federation in 20152016, which is represented in Table 5.

Table 5. The definition of the average per capita subsistence minimum in the Russian Federation during 2015-2016 (rubles per month)

\begin{tabular}{|c|c|c|c|c|c|c|c|c|}
\hline \multirow{3}{*}{ Indicator } & \multirow{2}{*}{\multicolumn{2}{|c|}{ Percapita }} & \multicolumn{6}{|c|}{ including per socio-demographic groups of the population } \\
\hline & & & \multicolumn{2}{|c|}{ Able-bodied population } & \multicolumn{2}{|c|}{ Holders of an annuity } & \multicolumn{2}{|c|}{ Children } \\
\hline & 2015 & 2016 & 2015 & 2016 & 2015 & 2016 & 2015 & 2016 \\
\hline IQuarter & 9662.0 & 9776.0 & 10404.0 & 10524.0 & 7916.0 & 8025.0 & 9489.0 & 9677.0 \\
\hline IIQuarter & 10017.0 & 9956.0 & 10792.0 & 10772.0 & 8210.0 & 8163.0 & 9806.0 & 9861.0 \\
\hline IIIQuarter & 9673.0 & 9889.0 & 10436.0 & 10678.0 & 7951.0 & 8136.0 & 9396.0 & 9668.0 \\
\hline IVQuarter & 9452.0 & 8903.0 & 10187.0 & 9749.0 & 7781.0 & 7246.0 & 9197.0 & 8870.0 \\
\hline
\end{tabular}

Having analyzed Table 5, we can conclude that the subsistence minimum in the Russian Federation increased in the $2^{\text {nd }}$ quarter of 2016 by 180.0 rubles., while in the $3^{\text {rd }}$ quarter of the same year it decreased by 33.0 rubles that indicates the change in the prices of the main components of the consumer basket.

Thus, we can conclude that per capita subsistence minimum in the Belgorod region is less than that in the Russian Federation in general, while the food basket is greater. Since the Belgorod region is rich in natural resources and characterized by actively developing import substitution at the expense of in-house production, the region can actively deliver the goods in both own region and other regions of the Russian Federation.

Also, having analyzed the consumer basket of the Belgorod region and comparing it with consumer baskets in other regions, we can conclude that it can be filled with much more products to increase the value of the goods already included into the basket. Such products include meat, vegetables, fresh fruit, eggs, butter, and bakery products,

A large part of the consumer basket in the Belgorod region is filled with the products related to in-house production that contributes to lowering prices and makes it possible to invest additional funds for needs in the sociocultural sphere.

\subsection{Contemporary Trends in Development of Regional Import Substitution Strategy}

In recent years the Belgorod region has successfully implemented an import substitution policy. Niche for the manufacturing of pipeline products for nuclear and thermal power plants is occupied in the region by the machinebuilding industry. It is beneficial for regional farmers to implement new projects in the field of animal production, grow vegetables in greenhouses, grow fruit and berries, as well as to be engaged in breeding and seed production.

Currently, agricultural machinery manufacturers are establishing successfully the production of spare parts, components and equipment for the needs of plant-growing and animal production. The biopharmaceutical cluster for the first time in the history of modern Russia is involved in the production of essential amino acids and Llysinesulfates, as well as in expanded production of veterinary drugs and medicines.

In 2016, the Belgorod region continued implementing action plan to promote import substitution.

At the moment, the list of projects contributing to import substitution consists of 86 promising projects totaling more than 160 bln rubles. The basic range of these projects scope cover dairy farming, production of vegetables, fruit and berries, seed production, manufacture of components for feed production, food processing, machine 
building, production of building materials, paints and lacquers, as well as the creation of new modern production of medicinal products.

While considering the implementation of investment projects in the machine-building industry, we can note OJSC 'Borisov Plant of Bridge Steel Structures named after V.A.Sklyarenko'. So, in May 2015, the construction of the steel structures manufacturing complex was completed that enabled the enterprise to increase the output of bridge structures up to 40 thousand tons of steel structures per year.

In December of 2015, LLC 'Belenergomash-BZEM' has put into operation a highly efficient industrial complex. The enterprise mastered the pipeline components production technology. The designed capacity of the complex is 18 thousand tons per year. The project is implemented in the framework of the import substitution strategy. It is assumed that the project will allow putting into operation the largest in Russia modernized pipe manufacturing complex. The area of production building will be 45 thousand square meters. The volume of investments in the project amounted to $3.6 \mathrm{bln}$ rubles.

The implementation of projects aimed at expansion, modernization, and technical re-equipment of enterprises is underway at enterprises such as:

- 'Rakityansky Valve Plant' JSC, where industrial complex is built to implement developed technology for longitudinal welded pipes production with the design capacity of 1000 tons per year;

- 'Wagon Wheel Workshop' LLC, where in 2017 manufacturing complex was launched to produce 200 thousand of solid-rolled railway wheel per year;

- 'SKIF-M' Ltd. has completed modernization of manufacturing facilities. The main goal of modernization was launching the production of inserted-blade milling cutters, which were designed for machining of high-strength titanium and nickel high-temperature alloys;

- 'StaryOskol Mechanical Plant' JSC has reconstructed and modernized production of shaped casting, and launched the production of pumping equipment for food and defense sectors;

- ZAO'Sokol-ATS' has reconstructed the production of aluminum assemblies and parts for civil and military aviation;

- LLC 'Stroyteplomontazh - Oskol' implements the project on creation of the 16 production sites for absorption lithium bromide refrigerating machines, as well as gas fired water and steam boilers in the framework of import-substituting in power equipment production.

The implementation of projects in the private industrial parks, including those involving small innovative enterprises, is one of the most effective growth points in the innovation development.

Governor of the Belgorod region has approved the program for development of industrial parks by 2020 . The 'North' industrial park is a pilot project in the form of public-private partnership, which has been launched in March 2015.

According to developed plan, it is assumed to establish industrial parks in the territory of each municipal area and city district. Work is underway to create an industrial park in the Stary Oskol urban district, the industrial zone in Gubkinsky urban district is under the development as well. In order to solve the import substitution problem, it is planned to create at least 30 industrial parks by 2020 in Belgorod agglomeration. The Department of Economic Development of the region and local authorities initiated within the project management the creation of 5 additional industrial parks together with the 'North' park.

The implementation of investment projects is an important tool for the agriculture development as well. Currently, the regional strategy of import substitution in agriculture includes 45 long-term projects. The increase in agricultural production is implemented in the framework of the Federal Law 'On procurement and deliveries of agricultural products, raw materials and food for state needs of enterprises, organizations, and institutions situated in the territory of the Russian Federation, irrespective of forms of ownership' that enables to increase production volumes of the food producing enterprises (Federal Law No. 264-FZ dated 29. 12.2006; Federal Law dated 19.07.2007. Collection of Legislation of the Russian Federation, 2007). In 2015, the plant engaged in oil refining was put into operation in the territory of the collective farm named after V.Y. Yuryev.

The 'EFKO' company has completed the project on construction of soybean processing plant and the plant for production of innovative dairy products. LLC 'MPZ Agro-Belogoreye' launches the second meat processing plant. LLC 'HochlandRussland' develops new technology to produce new types of cheese products.

LLC 'Belogorie Greenhouse Complex' constructed modern greenhouses and logistics center for under cover fruit and vegetable production.

'IZOVOL Agro' LLC has completed a project on the cut rose production in greenhouse complex.

Active works are underway on modernization of existing production facilities, such as modern industrial production complexes of highly efficient construction materials that meet the European quality. The ceramic bricks 
production plant with the capacity of $60 \mathrm{mln}$ equivalent units per year has been commissioned in the $1^{\text {st }}$ quarter of 2016. Underway is the construction of a cement plant with a capacity of $3 \mathrm{mln}$ tons per year, whose commissioning is scheduled for 2020 (The Decree of the President of the Russian Federation 2010).

Great attention is paid in the region to transport system development, including hauling stock and municipal equipment. It should be noted that the development of swine rearing in the Belgorod region and in Russia in general not only dramatically reduces the dependence on imports in pork consumption, but also becomes a kind of economic powerhouse for the development of related subsectors. As a consequence, the most significant changes associated with dependence on imports occurred in the areas such as the reproduction of breeding animals, production of animal complete feed and premixes. At the same time, veterinary preparations remain one of the most problematic areas of dependence on imports. This involves the production of amino acids, vitamins, as well as technological and refrigeration equipment. Obviously these are new future growth points of the agricultural sector in the region (Vlasova 2012).

In 2016, construction of modern enterprises of agricultural engineering was launched near Belgorod (Abelyan, Ivanova and Rudyk 2014). The uniqueness of the project lies in the fact that the project is implemented on a parity basis with the participation of the Russian company 'Agro-Belogorye' and the German 'Big Dachmen' and 'Schickling'. The product range of the plant will be focused on the animal production, processing and greenhouse business. The investment cost of the project is $9 \mathrm{mln}$ euro. The construction of such enterprises will result in the reduction of technological dependence of domestic agriculture on Western countries.

Thus, we can conclude that due to the combination of the available competitive advantages of the Belgorod region and the effective management model, as well as due to additional growth drivers in the form of import substitution strategies in response to food sanctions, and the growth of competitiveness of the Belgorod-produced goods on external markets due to the devaluation of the ruble, it is expected that in the medium term, the region will demonstrate the pace of development above the national average.

Development of industrial production is largely dependent on sustainable functioning of the mining enterprises. Their modernization improves the system of technical re-equipment of industry, leads to the implementation of new technologies for iron ore extraction and processing.

JSC 'Lebedinsky Mining and Concentration Complex' implements hot briquetting of metals and the latest technologies of metal processing in the framework of the ongoing project. The plant has built the outer pipeline and obtained favorable conclusion of the Directorate-General for State Environmental Review (Glavgos expertiza) of the Russian Federation concerning implemented technology and design.

JSC 'Stoilensky Mining and Concentration Complex', in accordance with the plant development program for 2011-2015, has expanded the open-cut mining of non-ferrous quartz rock from 32 to $42 \mathrm{mln}$ tons per year, as well as started the construction of the thickening unit and water recycling of tail facilities. In the framework of the project, construction of a pelletizing plant with a design capacity of $6 \mathrm{mln}$ tons of pellets per year was also carried out in 2013-2016. Construction works were carried out in accordance with an agreement concluded with a consortium of German and Finnish companies «SiemensVAI/Outotek». The project will allow the enterprise to move to progressive transportation of tailings (products, resulting from enrichment of ferruginous quartzites). Three similar projects were implemented by 2017 in the framework of the basic project.

'KMAruda Integrated Plant' OJSC operates the construction of cage and skip mine shafts in the framework of a long-term project aimed at increasing production capacity of the non-ferrous quartzites extraction plant of up to $7 \mathrm{mln}$ tons per year by building new mines.

'Metal-group' LLC continues implementing the underground mine project with a capacity of $4.5 \mathrm{~m} / \mathrm{n}$ tons of ore per year on the basis of the Yakovlevskiy deposit of rich iron ore.

Afavorable conclusion of the government expert review panel on industrial safety has been received with regard to the project on construction of the second phase of the 'Yakovlevsky'mine with an annual production capacity of $4.5 \mathrm{~m} / \mathrm{n}$ tons that will provide a gradual increase in plant capacity. The construction of production facilities and engineering infrastructure is underway to expand further the production capacity.

The industrial enterprises of the region carried out measures aimed at further increasing production of new types of competitive products.

To implement investment projects, processing enterprises expand their production. These projects are interrelated with the modernization, technical reequipment, and implementation of new technologies.

JSC 'Oskol Metallurgical Plant', in accordance with the renovation program of metallurgical complex, expects to increase steel production to $3.85 \mathrm{mln}$ tons per year, implement oxygen-permeable technology, as well as construct building No. 1 and the new oxygen plant, which will consist of a cryogenic air separation unit No. 3 of the German company Linde with a capacity of 20 thousand $\mathrm{m}^{3} / \mathrm{h}$. The plant was to be commissioned as early as the 
end of 2014. At present, the construction of the station building and the supply of compressor equipment are underway. In addition, the pelletizing and metallization shop No. 3 is being modernized.

In the framework of import substitution,projects on creation of new competitive industries are being implemented in the machine-building sector:

- JSC 'Energomash (Belgorod) - BZEM' is involved in the construction of high efficient industrial complex. This complex has implemented the advanced manufacturing technology of pipeline components. The design capacity is 12 thousand tons per year. The complex provides a full cycle of pipeline components manufacture for energy facilities. Also, the technology provides for the manufacture of pipes by the electroslagremelting method. The complex was commissioned in 2016. The project will allow the company to increase production volume by 1.6 times by 2017;

- 'Rakityansky Valve Plant' JSC implemented production lineto manufactureenergy facility components and units. The capacity of the plant is 600 tons per year. In 2013 the plant started implementing the project on construction of industrial complex to produce longitudinal welded pipes with the output capacity of 1000 tons per year;

- JSC 'Oskol Bearing Plant HARP' (OPZ HARP)plans to implementa new processing line, which will produce railway bearings with the capacity of 600 thousand items per year. The plant reached its designed capacity in 2016.

- 'Bilayt' LLC implemented a project in the territory of the Mechanical Repair Plant, LLC(Volokonovka). The projectaimed at running production line to manufacture design lamps. Annual production capacity amounted to 50 thousand items per month. The cost of the project was about 100 $\mathrm{mIn}$ rubles. The facility was commissioned in January 2014. The project implementation allowed creating over 50 new jobs.

In addition, some of the machine-building enterprises carry out a comprehensive implementation of reconstruction investment projects providing both technical reequipment and expansion of production volume:

- JSC 'Stary Oskol Automotive Electrical Equipment Plantnamed after A.M. Mamonov' is involved in the development of innovative casthouse production of components for high-tech devices, development of high-tech components manufacturing, namely ignition coils for electric blower pumps, submersible pump modules, and electronic transmission control systems with shift paddles. These productions aim at import substitution;

- 'Wagon Wheel Workshop' LLC is a modern enterprise providing services inmanufacturing and repair of wheel sets for rail cars. In 2017, the enterprise created car-repair depot to repair freight cars. By the end of 2017, the enterprise expects to reach design capacity for about 2 mInrailway cars per year;

- JSC 'Belgorod Abrasive Plant' has implemented production line for 'PeterSchwabe' grinding paper that allows producing automatically high quality products;

- LLC 'Innovator Plant' deals with the production of innovative structures based on upgrading of welded steel structures. The plant capacity is 25 thousand tons per yearthat will allow the enterprise to increase sales twice;

- JSC 'Boiler Equipment Plant' plans to increase output through the expansion of industrial areas and implementation of highly efficient equipment, namely 'AWSSchafer' pipe bending mill SRBI 400 that will allow the enterprise to produce pipeline components and enter new markets;

- ZAO'Sokol-ATS' carries out reconstruction of the manufacturing of main products, namelyhigh-tech targeted implementation of anodized lines to produce new products that will increase sales by 1.7 times;

- $\quad$ LLC 'Skif-M' carries out modernization targeted to produceinserted cutters for machining of hightemperature high-strength titanium and nickel alloys that will enable the enterprise to improve product competitiveness and expand sales markets;

- $\quad$ LLC 'ALTEK' has upgraded melting and casting facility for the preparation of raw materials in molten aluminum alloys withthe design capacity of at least 16.8 thousand tons. This technology will allow increasing production of aluminum alloys to 16.8 thousand tons per year by the end of the current year;

- LLC 'Oskolneftemash' has launched the project on implementation of technology to produce components used in the oil extraction pumps. The components are made of high-alloy cast iron with subsequent mechanical machining. The cost of the project amounted to $1 \mathrm{bln}$ rubles. After reaching the design capacity of 2,500 tons per year, 350 new jobs will be created at the plant.

A cement plant with a capacity of $3 \mathrm{mln}$ tons per year and a plant for ceramic bricks production with the capacity of $60 \mathrm{mln}$ pieces per year will be commissioned in Krasnogvardeysky district in 2018. 
In order to saturate the domestic market with quality and affordable food products, the region implements the program titled 'Development of agriculture and fish-farming in the Belgorod region for 2014-2020'. The implementation of scheduled measures will lead to increased effectiveness and competitiveness of agricultural production.

The Belgorod region is a leading region in terms of product supply to the domestic market. So, in the

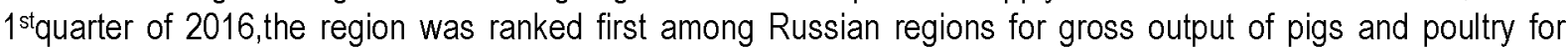
slaughter (in live weight), grown in agricultural enterprises of the region. Besides, the region was ranked $3^{\text {rd }}$ among the regions of the Central Federal District for milk production.

To retain dominant position in the plant-growing, the Belgorod region improves the structure of sowing and crop rotation, widely implements the latest high-yielding varieties and hybrids of agricultural crops, develops resource-saving technologies of soil treatment, uses high-performance wide-cut equipment, as well as satellite navigation in fertilizing, sowing, treatment of crops and the harvesting. Besides, the regional enterprises implement green manure crops and planting fillers, as well as use direct sowing technology of all kinds of crops in order to reduce the negative impact of economic and natural risks. Biological farming systems, as well as the transition of agricultural production manufacturers of all forms of ownership to differentiated technology-based rotations, are actively implemented to increase the area of perennial grasses.

\section{Discussion}

\subsection{Performance Evaluation of State Regulation Measures of the Import Substitution Policy}

A Decree of the President of the Russian Federation dated August 6, 2014 and resolutions of the Russian Government concerning banning the import of food products from some Western countries opened, in fact, a new page in domestic food processing industry development. Food security issues in the Russian Federation are becoming increasingly urgent. One of such challenges is an issue concerning investment support for import substitution of food products (Polovinkin and Fomichev 2014).

A comprehensive assessment of the effectiveness of import substitution implementation is characterized by the difference between the approaches to methods of determining the level of food security that greatly complicates the task of selecting a proper methodology (A meeting of the Presidium of the Presidential Council of the Russian Federation devoted to economy modernization and innovative development of Russia. Center for Humanitarian Technologies 2014).

In consequence of the events of the last two years (problems related to sanctions and counter-sanctions, the fall in oil prices, and devaluation of the national currency), the scientific literature has been enriched with various articles devoted to the analysis of food self-sufficiency, as well as the strategy of import substitution in agriculture. Note that the import substitution and food self-sufficiency issue is quite extensive. Therefore, in the framework of the present research we shall be limited to the consideration of regional level.

Regional and federal food self-sufficiency issues are considered in many research works, therefore, we will develop some ideas concerning the methodology to determine the level of food self-sufficiency in the region. Five areas of the Central Chernozem economic region will be considered as the research objects, while the regional meat and milk markets will be the subject of the study. The studies were carried out in the time frame from 2013 to 2016.

There are several approaches to determining the level of food self-sufficiency of the region. The most popular approaches are described below:

$$
L=\frac{M}{C} \times 100 \% \text {, }
$$

where, $L-$ is the level of food self-sufficiency in the region, \%;

$\mathrm{M}$ - is the per capita product manufacturing, $\mathrm{kg} / \mathrm{year}$;

$\mathrm{C}$ - is the per capita product consumption, $\mathrm{kg} / \mathrm{year}$.

$$
L=\frac{C}{R} \times 100 \%
$$

where, $L-$ is the level of food self-sufficiency of the region, \%;

$\mathrm{C}$ - is the per capita product consumption, kg/year;

$\mathrm{R}-$ is the rational consumption rate, $\mathrm{kg} / \mathrm{year}$. 


$$
\mathrm{L}=\frac{M}{C} \times 100 \%,
$$

where, $L-$ is the level of food self-sufficiency of the region, \%;

$\mathrm{M}-$ is the in-house product manufacturing, thousand tons/year;

$\mathrm{C}-$ is the private consumption of products, thousand tons/year.

Above techniques to determine the regional level of food self-sufficiency are characterized by certain limitations, which are caused by averaged indicators that do not allow carrying out more detailed assessment. It should be noted that none of these methods reflects the level of purchasing power of the population, and this is a significant drawback. We believe that the discussion on the issues of definition of food self-sufficiency in the region still remains open and requires further study to account for the most important characteristics in consumer behavior of the population (Bagrinovskii and Matyushok 1999).

As an example, let's carry out calculations for the Belgorod region using the first method. All data are available from the Rosstat website. In 2016, the consumption of food products, namely milk, by the population of Belgorod region was $260.0 \mathrm{~kg} / \mathrm{year}$. The per capita amount of milk produced in the Belgorod region in 2016 amounted to $472.0 \mathrm{~kg} / \mathrm{year}$. Now let's calculate self-sufficiency level for milk in the region:

$$
L=\frac{472}{260} \times 100 \%=181.53
$$

In 2016, the consumption of food products, namely meat, by population of the Belgorod region was 77.0 $\mathrm{kg} / \mathrm{year}$. Per capita meat production in the Belgorod region in 2016 was $525.50 \mathrm{~kg} / \mathrm{gnaw}$ let's calculate selfsufficiency level for meat in the region:

$$
L=\frac{525.5}{77} \times 100 \%=682.4
$$

Thus, we can conclude that the Belgorod region is relatively self-sufficient region. With the per capita meat production of $525.5 \mathrm{~kg} / \mathrm{year}$, the Belgorod region has overtaken Moscow and 16 other regions. In terms of milk production, the Belgorod region is ranked second after the Voronezh region.

\subsection{Shaping Priority Guidelines of Import Substitution in the Context of Increasing the Economic Security of the Belgorod Region}

In order to implement effective development of import substitution in the Belgorod region, we offer to establish at the regional level the commission for import substitution regulation on the basis of the Department of agro-industrial complex and environment reproduction of the Belgorod region. Note that the Department of agro-industrial complex and environment reproduction of the Belgorod region represents the regional executive authority, which performs state regulation of the agricultural sector and environment reproduction in the region. The Departments also engaged in management and coordination of the specified fields of activity that ensures holding of a unified state policy in the sphere of agriculture and the environment reproduction in the region.

The Department performs its functions directly or in cooperation with federal bodies of executive power and their territorial bodies, regional executive authorities, state authorities of the region, local self-government bodies, public associations, regional agricultural producers regardless of their organizational-legal forms, patterns of ownership and subordination, as well as with other bodies and organizations. In our opinion, the structure of the commission on import substitution in the Belgorod region should look like the following (Figure 1). 


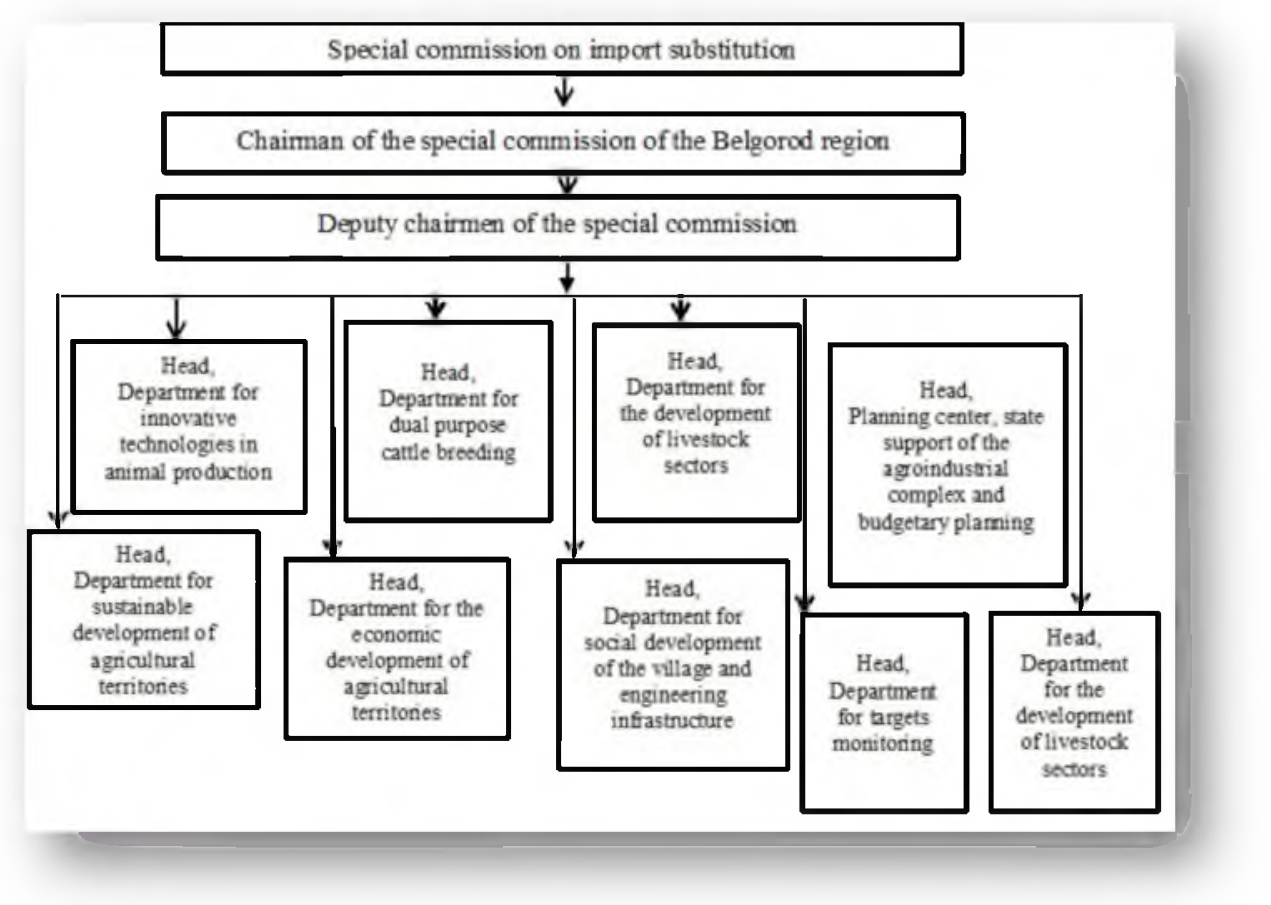

Figure 1. The structure of the regional commission on import substitution In the Belgorod region

Special regional commission on import substitution is represented as a coordinating body, which is established in order to ensure concerted actions at the regional level to implement regional policy in the import substitution, as well as reducing the dependence of industries on imports.

The special commission is guided in its activity by the Constitution of the Russian Federation, Federal Constitutional Laws, Federal Laws, memorandums of the Russian Federation President and the Government, as well as local laws adopted at the level of the Belgorod region.

Let us define the main tasks of the special commission. They are as follows:

(1) ensuring concerted actions at the level of the Belgorod region, when defining the main regional policy directions in the field of import substitution and implementation of measures in specified key areas;

(2) accomplishing a monitoring system for implementation of the specified main aspects;

(3) considering the proposals, which are aimed at creating conditions for the effective implementation of regional import substitution policy;

(4) considering issues related to the implementation and improvement of activities of executive power bodies, local self-governing authorities, and organizations in the region, when implementing the import substitution policy;

(5) considering issues related to the implementation of long-term development and investment programs of the entities of the Belgorod region, as well as organizations with state participation with regard to implementation of state policy in the field of import substitution;

(6) identifying measures that are aimed at meeting the needs of the domestic market in industrial products of Russian production;

(7) identifying the basic measures that are aimed at enhancing the investment attractiveness of projects in the field of import substitution;

(8) coordinating activities of regional bodies of executive power in order to establish the production of goods, works, and services that do not have Russian analogues and recognized as priority, for import substitution taking into account the needs of the relevant sectors of the economy.

Meeting of the special commission is conducted by the chairman or, in his absence, by the deputy chairman. Meetings of the special commission should be held at least once in three months. If necessary, extraordinary meetings can be held. Meeting of the special commission is considered competent before the law if attended by more than half of its members. The special commission members participate in the meetings without the right to be replaced. If any member of the special commission is absent at the meeting, he has every right to present his 
opinion on the issue under consideration in writing. The adopted decisions of the special commission are drawn up by the minutes of the meeting, which are signed by the chairman.

Thus, the special commission on import substitution will allow coordinating the activities of the Department and achieving a higher level in concerned area that will improve the economic security of the region and the country in general.

\section{Conclusions}

Thus, we have conducted an analysis of the food basket in the Belgorod region comparing it with the food basket in the Russian Federation. In consequence of the analysis we can conclude that in the Belgorod region, on average, the amount of food products per person is greater than that in the Russian Federation in general. Consumer basket in the Belgorod and Murmansk regions is filled with much greater amount of essential products, despite the fact that the Belgorod region as distinguished from the Murmansk region has its own production of these goods and more developed ways of communication. Besides, we have analyzed current status of the regional import substitution system in the Belgorod region and concluded that the region holds a leading position in supplies of livestock products on the domestic market. We have proposed the technique to assess the effectiveness of state regulation measures in the import substitution sphere.

From the presented analysis we can conclude that the Belgorod region is self-sufficient. In terms of meat production at $525.5 \mathrm{~kg}$ per capita, the concerned region is in advance of the capital and 16 regions. The volume of milk production in the region is on the second place after the Voronezh region. Thus, we can conclude that the regions of the Russian Federation are self-sufficient in terms of food products. This situation suggests that the country's food security is at a quite high level. This allows increasing the economic security of the country in general. The proposed special commission on import substitution will allow coordinating the activities of the Department and achieving a higher level in the concerned area that will improve the economic security of the region and the country in general.

\section{References}

[1] A meeting of the Presidium of the Presidential Council of the Russian Federation devoted to economy modernization and innovative development of Russia. Center for Humanitarian Technologies. 24.11.2014 from http://www.governvent.EN/ news/15780/ (accessed 7.09.2017).

[2] Abelyan, A.S., Ivanova, N.E., and Rudyk, E.V. 2014. Mekhanizmy importozameshcheniya $v$ politike modernizacii rossijskoj ehkonomiki: prakticheskij instrumentarij realizacii [Mechanisms of import substitution in the modernization policy of Russian economy: A practical implementation toolkit] [Text]. Transport Issues of Russia, 4, 114-116.

[3] Bagrinovskii K.A. and Matyushok, V.M., 1999. EHkonomiko-matematicheskie metody i modeli (makroehkonomika) [Mathematical and economic methods and models (macroeconomics)] [Text]. Moscow: Peoples' Friendship University of Russia, RUDN University Publishing House, pp. 183.

[4] Central statistical database. (n.d.). Analytics. http://www.aks.ru/dbscripts/Cbsd/DBInet.cai.

[5] Maslov, D.V. 2014. Importozameshcheniekakvektorrazvitiyastranypredpriyatiya [Import substitution as the country's development vector] [Text]. Economy and Society, 2-3(11), 293-298.

- prozhitochnom minimume v Rossijskoj Federacii [On subsistence minimum in the Russian Federation] [Text]. Federal Law No. 134-FZ dated 24.10.1997.

- razvitii sel'skogo hozyajstva [On the development of agriculture] [Text]. Federal Law No. 264-FZ dated 29. 12.2006. Rossiyskaya Gazeta, 11.01.2007.

- zakupkah i postavkah sel'skohozyajstvennoj produkcii, syr'ya i prodovol'stviya dlya gosudarstvennyh nuzhd predpriyatiyam, organizaciyam i uchrezhdeniyam, raspolozhennym na territorii Rossijskoj Federacii, nezavisimo ot form sobstvennosti [On procurement and deliveries of agricultural products, raw materials and food for state needs of enterprises, organizations, and institutions situated in the territory of the Russian Federation, irrespective of forms of ownership] [Text]. Federal Law dated 19.07.2007. Collection of Legislation of the Russian Federation, 2007, No. 32. Item 3303. 
[6] Ob utverzhdenii Doktriny prodovol'stvennoj bezopasnosti Rossijskoj Federacii [On approval of food security Doctrine of the Russian Federation] [Text]. The Decree of the President of the Russian Federation No. 120 dated 30.01.2010. Rossiyskaya Gazeta, 21, 03.02.2010.

[7] Polovinkin, V.N., and Fomichev, A.B. 2014. Problemy importozameshcheniya v otechestvennoj ehkonomike [The import substitution challenges in the Russian economy] [Text]. Expert Alliance, 12(42), 43-46.

[8] Vlasova, I.G. 2012. Importozameshchenie i prodovol'stvennaya bezopasnost' [Import substitution and food security] [Text]. Journal of Russian Entrepreneurship,5(2), 150-155. 